\title{
A novel surgical technique for prevention of self- sucking in cattle and buffaloes: Tongue piercing
}

Al-Lethie Al-Lethie ( $\sim$ lithy@aswu.edu.eg )

Aswan University

Yasser salman

Aswan University

Mohamed Semieka

Assiut University

Mohamed Karmi

Aswan University

\section{Research Article}

Keywords: Cattle, Buffaloes, Self-sucking, Tongue piercing

Posted Date: March 7th, 2022

DOI: https://doi.org/10.21203/rs.3.rs-1340459/v1

License: (c) (1) This work is licensed under a Creative Commons Attribution 4.0 International License.

Read Full License 


\section{Abstract}

Background: Self-sucking is an abnormal behavior lead to important economic losses for dairy farms. The objective of this study was to evaluate tongue piercing as a novel technique to prevent self-sucking in cattle and buffaloes. The study was carried out on 26 cows and 4 buffaloes suffered from selfsucking. Tongue piercing was achieved by the application of an implant in the midline of the tongue and anterior to the frenulum linguae. With a follow up period of six months.

Results: This implant produced mechanical disruption of the affected animals ability to curl their tongues, in a U-shape manner, subsequently it was impossible for these animals to cup their tongues and suck its own teats. Slight swelling around the piercing site of the tongue was observed among all animals on the first three days after surgery. No other complications have been reported.

Conclusion: Tongue piercing is an effective, rapid, easy, minimally invasive technique to prevent selfsucking among cattle and buffaloes, moreover, the technique was more widely acceptable by the owners than other traditional and surgical methods.

\section{Background}

Self-sucking is an abnormal behavior in dairy farms in which the affected animals curl their tongues into a $U$ shape for the purpose of sucking milk from their own teats [1].

Various factors can influence the occurrence of self-sucking, including feeding management, nutrient deficiencies, housing systems and genetic factors [2-5].

Self-sucking causes significant financial losses for dairy farms by lowering milk yield and causing udder damage and mastitis. Moreover, the affected animal can be left out of breeding in early periods due to only this kind of behavioral defect [5].

To prevent self-sucking, a variety of conservative methods (halters or cradles, pronged nose rings, weaning rings, and nose flaps) were used, but these devices did not solve the problem and could result in severe injuries to the affected animal as well as neighboring animals. Additionally, the affected animal becomes economically ineffective because it is regarded as of lower quality in markets, so surgical intervention has proven to be the most effective solution [6-8].

A variety of surgical techniques were used for the prevention of self-sucking. These techniques were designed to prevent animals from being able to cup the dorsum of their tongues and suck teats, including the ventral glossectomy technique [7-10] and the lateral glossectomy technique [11, 10]. Recently, two less-invasive techniques were performed by applying silk stitches to the free portion of the tongue $[12$, 13]. However, these techniques varied in their complications and success rates. This prompted us to find a better surgical technique to prevent this abnormal behavior. 
Body piercing is the insertion of an ornament into openings in the skin or mucosa [14]. Body piercing has been used as a type of body adornment since ancient times, both for ritual or aesthetic reasons, as well as to declare one's membership in a particular social or ethnic group. Piercing is now very popular among young adults and teenagers as a means of self-expression [15]. Despite the fact that the ear is still the most popular piercing location, the orofacial area, which includes the nose, lips, cheeks and, in particular, the tongue, is growing in popularity [16]. There are various forms of tongue piercings and the most common forms are barbells, rings or studs of different lengths and thicknesses that are inserted through the tongue. It is most commonly performed in the midline of tongue, but it can also be performed laterally to the midline [17].

The purpose of this research was to assess the tongue piercing technique as a new method for the prevention of self-sucking in cattle and buffaloes.

\section{Results}

All of the affected animals' physiological parameters were normal enough to perform this surgical technique. Following the procedure, the vital parameters continue to remain within normal physiological limit values.

Slight bleeding was observed at the puncture site of the trocar insertion; however, no other intra operative complications were recorded. The blood vessels and nerves of the tongue were not invaded and remained intact.

There was no further bleeding after the tourniquet was removed. Slight swelling around the tongue piercing site was observed in all animals during the first three days after surgery.

In all treated cases, the animals' normal prehension of all types of feed was unaffected, and all animals were able to eat and drink properly immediately after the surgical procedure.

A six-month follow-up examination revealed that self-sucking had completely disappeared in all of the treated animals.

\section{Discussion}

Self-sucking is a common problem in dairy animals, resulting in milk loss as well as udder damage, mastitis, and breeding animal culling [18].

In the present study, despite several trials of isolation and application of bull rings with spikes, the problem persisted and there was a great fear of the spread of this anomalous behavior by imitation from the neighboring cows. This agrees with Abou-El-Ella [7] who stated that due to the failure of all traditional control methods such as isolation and application of bull rings with spikes, the surgical interventions are 
the last trial to resolve the problem and the long-term benefits from the surgical procedures are more satisfactory than the conservative methods.

The previous glossectomy techniques for treatment of this problem relied on the surgical excision of varying thicknesses of tongue tissues to disrupt the tongue's contour and prevent it from curling, making milk suction difficult. The procedures of these techniques are time-consuming, may necessitate general anesthesia and result in tongue tissue damage, which can lead to bleeding and sepsis. Furthermore, determining the precise size and thickness of the tongue tissue to be excised is a major challenge with these techniques [12].

El-Sherif and Seddek et al. $[12,13]$ performed less-invasive surgical methods by applying silk stitches to the tissues of the tongue to make the tongue's dorsal surface convex to prevent this abnormal behavior. These techniques had a low success rate in the long term because the amount of tongue tissue involved in the stitches was less than the minimum amount required to make a change in the tongue contour, so the animals could theoretically continue sucking after surgery [8-10]. Furthermore, prolonged use of nonabsorbable multifilament braided suture material with a high capillary ascension in the moist environment of the oral cavity promotes bacterial infections, which could lead to glossitis or the formation of a tongue abscess $[19,20]$.

In the current study, the piercing implant created mechanical disruption of the affected animals' ability to curl their tongues in a U-shape, rendering these animals unable to cup their tongues and suck milk from their own teats. Here, the tongue has the ability to perform its function efficiently after the operation and all animals were allowed to drink and eat freely after the operation compared with other surgical techniques. The food was offered after 12 hours in the sublingual-mucosal-resection technique and after 24 hours in the partial glossectomy technique. This may be attributed to the post-operative pain associated with these techniques, which dissuades the animals from feeding [21].

In this study, tongue piercings are performed with a sheep stainless trocar with cannula and the implant consists of a barbell with two screws; one is fixed and the other is removable. In humans, barbells are the most common implant placed in the tongue after it has been pierced with a hollow needle. It is made up of a stem that varies in length and has a ball-shaped tip on each end [22].

In humans, tongue implants are made from a variety of different materials such as surgical stainless steel, silver and gold, as well as synthetic materials such as teflon, nylon, and plastic. Recently, implants made of natural materials such as stone, wood, horn, ivory and bone have been developed [23]. In the present study the implant was made of plastic material, which is characterized by its superior biocompatibility [24].

In this study, the tongue is pierced dorsoventrally, and the implant is inserted in the midline of the tongue, anterior to the frenulum linguae, from the dorsal surface to the ventral surface. Peticolas et al. [22]described two kinds of tongue piercing. The dorsoventral is the most common and harmless 
technique. The dorsolateral piercing in which, the implant is placed along the lateral edges of the tongue. Because the lateral tongue is highly vascularized and innervated, this is not a risk-free procedure.

The piercing procedures in the present study were performed under sedation and local infiltration analgesia and this agrees with Farah and Harmon, [25] who said that piercing in people is not a painful procedure and carried out without anesthetic and mainly performed by nonmedical self-trained individuals or dental personnel with varying degrees of proficiency.

Because human oral microflora is diverse and abundant, it's important to keep the pierced area clean, and antiseptic mouthwash must be used three to four times per day until the entire healing process is completed and if a patient complains of pain, oedema, and an inflammatory reaction from tongue piercing, the implant should be removed, local debridement performed, and antiseptic, anti-inflammatory, and antimicrobial treatment administered to hasten healing and resolve the problem [25].

Jornet et al. [26] performed tongue piercing in dogs and clinically found that none of the implants caused significant edema or hemorrhage, as well as none of the complications associated with human piercing. Pathologically, the piercing canal had been completely re-epithelialized at the expense of the healthy epithelium at the surgical wound's edge.

In the present study only slight swelling around the piercing site of the tongue was recorded in all animals on the first three days after surgery and no other complications have also been reported. This may be attributed to the large number of salivary glands in ruminants that contribute to the production of large amounts of saliva, which can reach $100 \mathrm{~L}$ per day in adult cattle [10]. Saliva has been shown to hasten the wound healing process for a variety of reasons. Saliva produces moist environment, which improves the viability and activity of inflammatory cells, which are essential for wound healing; saliva has plenty of tissue factor, which helps blood clot faster. Furthermore, saliva includes a variety of peptides and proteins which provide protection against microbial pathogens by inhibiting bacterial adhesion and neutralizing microbial toxins $[27,28]$.

\section{Conclusions}

Finally, none of the complications of the previous methods were observed in this study and the piercing technique had a lot of advantages like its quicker nature as it can be considered a one-shot surgical technique and less-invasive nature due to the preservation of tongue tissues with minimal intra-operative pain. Furthermore, the piercing technique was accepted by the owners due to its ability to solve the problem with low cost and rapid return of the operated animal to normal foot intake and productivity.

\section{Methods}

\section{Ethical approval}


All procedures in this study have been approved by the National Ethical Committee of the Faculty of Veterinary Medicine, Aswan University, Aswan, Egypt. All methods were carried out in accordance with relevant guidelines and regulations. All methods are reported in accordance with ARRIVE guidelines. Animals are cared for and used in research and education in accordance with Egyptian laws and OIE animal welfare guidelines. The owners signed an informed consent form to use the animals in the current study.

\section{Animals}

The study was conducted on 26 cows and 4 buffaloes that belonged to private owners in Aswan governorate, Egypt, (ages ranged from 3 to 6 years) suffered from self-sucking behavioral disorder. These animals were selected for this technique after the failure of several trials of isolation, application of bull ring with spikes and after approval of the animals' owners.

\section{Pre-operative clinical examinations:}

Before surgery, physiological parameters such as rectal temperature, heart rate, and respiratory rate were assessed to determine whether an individual animal was healthy enough to undergo this surgical technique.

\section{Surgical procedures}

Tranquilization was acquired by administering xylazine $\mathrm{HCl}$ 2\% (Xyla-Ject, Adwia Company, Egypt, injectable solution, xylazine hydrochloride $23.3 \mathrm{mg}$, eq. to $20 \mathrm{mg}$ xylazine base) at a dose rate of 0.05 $\mathrm{mg} / \mathrm{kg}$ body weight of the animal for operations that were performed in a recumbent position and at a dose rate of $0.01 \mathrm{mg} / \mathrm{kg}$ body weight of the animal for operations that were performed in a standing position.

The oral cavity was flushed with povidone iodine solution 1\% (Betadine-mouth wash, El- Nile Company for Pharmaceutical industries, Cairo, Egypt). The tongue was grasped gently, disinfected with povidone iodine solution $10 \%$, and a tourniquet (made of rolled gauze) was circumferentially applied to the base of the tongue as close to the frenulum linguae as possible. The operative area on the dorsal surface of the tongue is marked with a pen, usually along the midline and anterior to the frenulum linguae. Lidocaine $\mathrm{HCl}$ 2\% (Chemicals Company for El-Debeiky Pharma, Egypt) was locally infiltrated into the lingual submucosa of the operative site.

Tongue piercings were performed with a sheep stainless trocar with cannula. The implant consists of a barbell with two screws; one is fixed and the other is removable, made of plastic material (Fig. 1) 
The trocar and cannula pierced the tongue in a dorsal-ventral direction. The trocar was then removed and the barbell was inserted through the cannula traversing the tongue. Once the barbell was in place, the cannula was removed, and the removable screw was screwed into place with a pair of pliers and the bandage was removed.

The oral cavity was irrigated with povidone iodine solution $1 \%$ twice daily for three successive days. Animals were allowed to drink and eat freely after the operation. The owners were instructed to observe the treated animals and document any attempts by the treated animals to suck themselves. All treated cases were followed for up to six months to see if there were any complications (Fig. 2-7).

\section{Declarations}

\section{Ethics approval and consent to participate}

All procedures in this study have been approved by the National Ethical Committee of the Faculty of Veterinary Medicine, Aswan University, Aswan, Egypt. All methods were carried out in accordance with relevant guidelines and regulations. All methods are reported in accordance with ARRIVE guidelines. Animals are cared for and used in research and education in accordance with Egyptian laws and OIE animal welfare guidelines. The owners signed an informed consent form to use the animals in the current study.

\section{Consent for publication}

'Not applicable'

Availability of data and materials

All data generated or analysed during this study are included in this published article.

\section{Competing interests}

"The authors declare that they have no competing interests"

\section{Funding}

'Not applicable'

\section{Authors' contributions}


All authors conducted the study equally, analyzed and discussed the results, wrote and approved the final manuscript.

\section{Acknowledgements}

'Not applicable'

\section{References}

1. Martinez-de la Puente, J., I. Moreno-Indias, A. Morales-Delanuez, M. D. Ruiz- Díaz , L. E. HernándezCastellano, N. Castro, and A. Argüello.. Effects of feeding management and time of day on the occurrence of self-suckling in dairy goats. Veterinary Record. 2011; 168:378-382.

2. Keil, N. M., Audigé, L., \& Langhans, W.. Is intersucking in dairy cows the continuation of a habit developed in early life? Journal of Dairy Science. 2001; 84(1), 140-146.

3. Lidfors, L., \& Isberg, L. Intersucking in dairy cattle-review and questionnaire. Applied Animal Behavior Science. 2003; 80(3), 207-231.

4. Savagea, A. F., Maulla, J., Tiana, X. C., Tanejaa, M., Katzb, L., DARREA, M. \& Yang, X. Behavioral observations of adolescent Holstein heifers cloned from adult somatic cells. Theriogenology. $2003 ; 60,1097-1110$.

5. Bademkiran, S., Celik, R., Yesilmen, S., Kanay, B. E., \& Kilinc, M.. The effects of self-sucking on daily milk product, udder health and the form of the teats of dairy cows. Journal of Animal and Veterinary Advances. 2007; 6(11), 1250-1254.

6. Allmacher, G.. Mouth-Nose ring to prevent cattle from sucking. Deutsche tierarztliche Wochenschrift. 1998; 105(3), 104-105.

7. Abou-El-Ella, A. G. Surgical treatment of anomalous milk sucking in Friesian dairy cattle. Assiut Veterinary Medical Journal. 1999; 42, 260-270.

8. Bademkiran, S., Üstün, B., \& Kanay, B. E.. Application of some methods to prevent of self-sucking in dairy cattle in Diyarbakır Province. YYÜ Vet Fak Derg. 2006; 17(1-2), 59-64.

9. Yong, H., Cho, J., \& Kim, S.. Tongue surgery of a cow showing a constant inter sucking behavior. Journal of Veterinary Clinics. 2008; 25(2), 136-138.

10. Ducharme, N. G., Desrochers, A., Fubini, S. L., Pease, A. P., Mizer, L. A., Walker, W., et al. Surgery of the bovine digestive system. In N. G. Ducharme, \& S. L. Fubini (Eds.). Farm animal surgery. (2nd Edn.). St. Louis, Missouri: Elsevier. 2017; (pp. 223-343).

11. Berthet, A., Debreux, A., \& Coustumier, J. Surgical treatment of teat sucking in cattle 'Lingual apexectomy'. Bulletin Mensuel de la Societe Veterinaire Pratique de France. 1981; 65(1), 71-81.

12. El-Sherif, M. W.. Tongue reshaping: A new surgical method to prevent self-sucking in dairy cows. Open Veterinary Journal. 2018; 8(2), 140-143. 
13. Seddek, M. Abdelfattah, M.H. Elrashidy, F.A. Mahmoud, F.A. Zakaib. Intra-lingual suture pattern for prevention of self-suckling in cows. Veterinary and Animal Science. 2019; 8, 100062.

14. Plessas A, Pepelassi E. Dental and periodontal complications of lip and tongue piercing: prevalence and influencing factors. Aust Dent J 2012; 57: 71-78.

15. Covello F, Salerno C, Giovannini V, Corridore D, Ottolenghi L, Vozza I. Piercing and Oral Health: A Study on the Knowledge of Risks and Complications. Int J Environ Res Public Health. 2020; 17(2): 613.

16. Krause H, Bremerich A, Sztraka M. Komplikationen nach Piercing im Mund und im Gesicht [Complications following piercing in the oral and facial region]. Mund Kiefer Gesichtschir. 2000; 4(1):21-4.

17. De Moor RJ, De Witte AM, De Bruyne MA. Tongue piercing and associated oral and dental complications. Endod Dent Traumatol. 2000; 16(5):232-7.

18. Ahmed I. A, Helal M. A, Ramadan S. G, Mahboub H.D, Byomi A. M , Reddy P.G. Risk Factors Associated with Galactophagia and Its Impacts on Some Productive and Reproductive Traits in Dairy Cows and Buffaloes. Research and Reviews: Journal of Dairy Science and Technology. 2014; Volume 4, Issue 2.

19. Geiger, D., Debus, E. S., Ziegler, U. E., Larena-Avellaneda, A., Frosch, M., Thiede, A., et al. Capillary activity of surgical sutures and suture-dependent bacterial transport: A qualitative study. Surgical Infections. 2005; 6(4), 377-383.

20. Silver, E., Wu, R., Grady, J., \& Song, L.. Knot security - How is it affected by suture technique, material, size, and number of throws? Journal of Oral Maxillofacial Surgery. 2016; 74(7), 1304-1312.

21. Jennings, P.B. The Practice of Large Animal Surgery. W.B. Saunders Company, Philadelphia. 1984; Vol. 1. 501-502.

22. Peticolas T, Tilliss TS, Cross-Poline GN. Oral and perioral piercing: a unique form of self-expression. J Contemp Dent Pract. 2000; 1(3):30-46.

23. Ziebolz D, Stuehmer C, van Nüss K, Hornecker E, Mausberg RF. Complications of tongue piercing: a review of the literature and three case reports. J Contemp Dent Pract. 2009; Nov 1;10(6):E065-71.

24. Peter R. Lantos. Plastic in medical applications. Journal of Biomaterials Applications. 1988; volume 2:358-71.

25. Farah CS, Harmon DM. Tongue piercing: case report and review of current pratice. Aust Dent J. 1998; 43: $387-9$.

26. Lopez Jornet P, Vicente Ortega V, Yanez Gascón J, Cozar Hidalgo A, Perez Lajarin L, Garcia Ballesta $C$ et al. Clinicopathological characteristics of tongue piercing: an experimental study. J Oral Pathol Med. 2004; 33: 340-5.

27. Varshney AC, Sharma DN, Singh M, Sharma SK, Nigam JM. Therapeutic value of bovine saliva in wound healing: a histomorphological study. Indian J Exp Biol. 1997; 35: 535-537. 
28. Brand, H. S., Ligtenberg, A. J., \& Veerman, E. C.. Saliva and wound healing. Monographs in Oral Science. 2014; 24, 52-60. https://doi.org/ 10.1159/000358784.

\section{Figures}

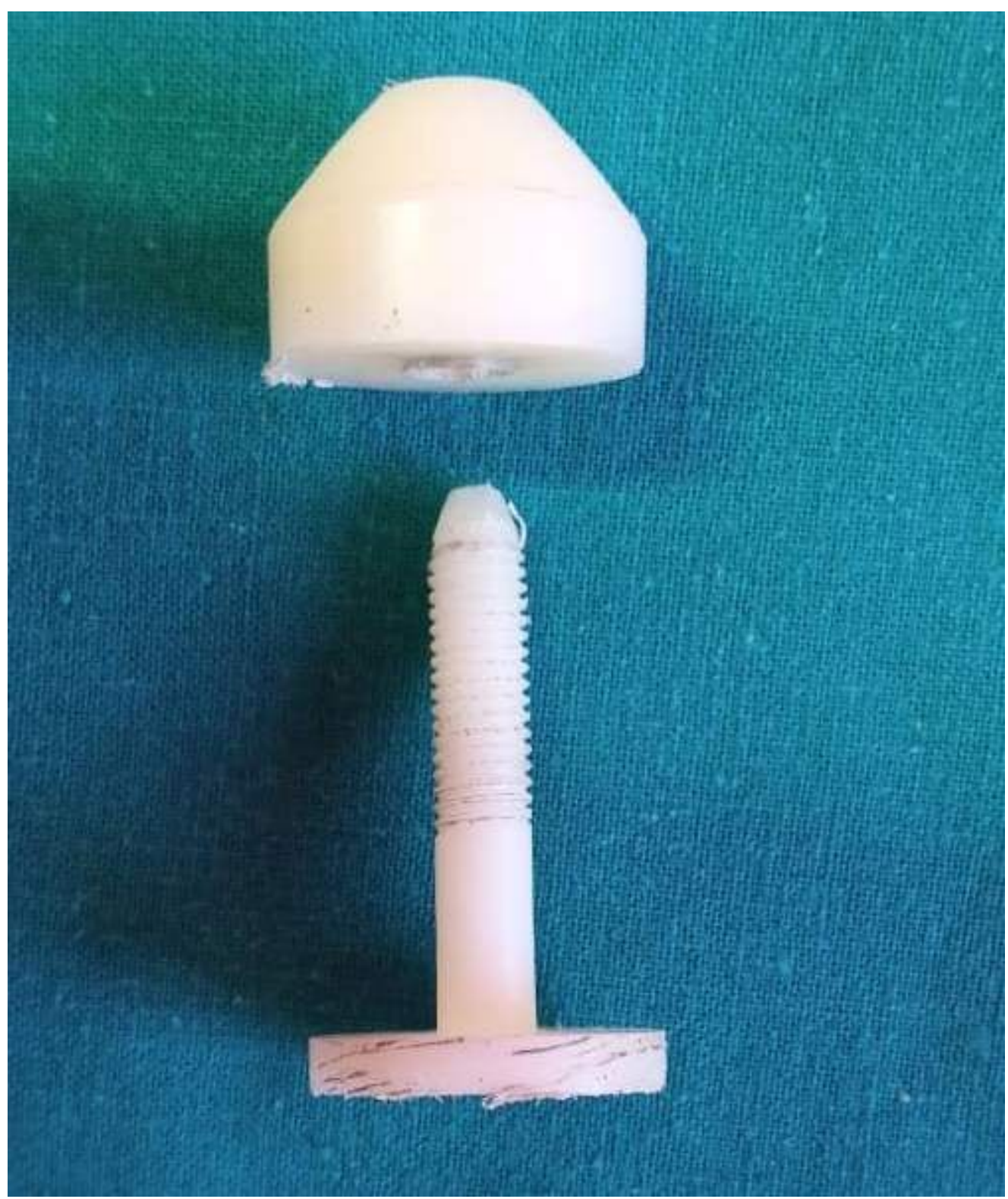

\section{Figure 1}

The implant consists of a barbell with two screws; one is fixed and the other is removable and made of plastic material. 


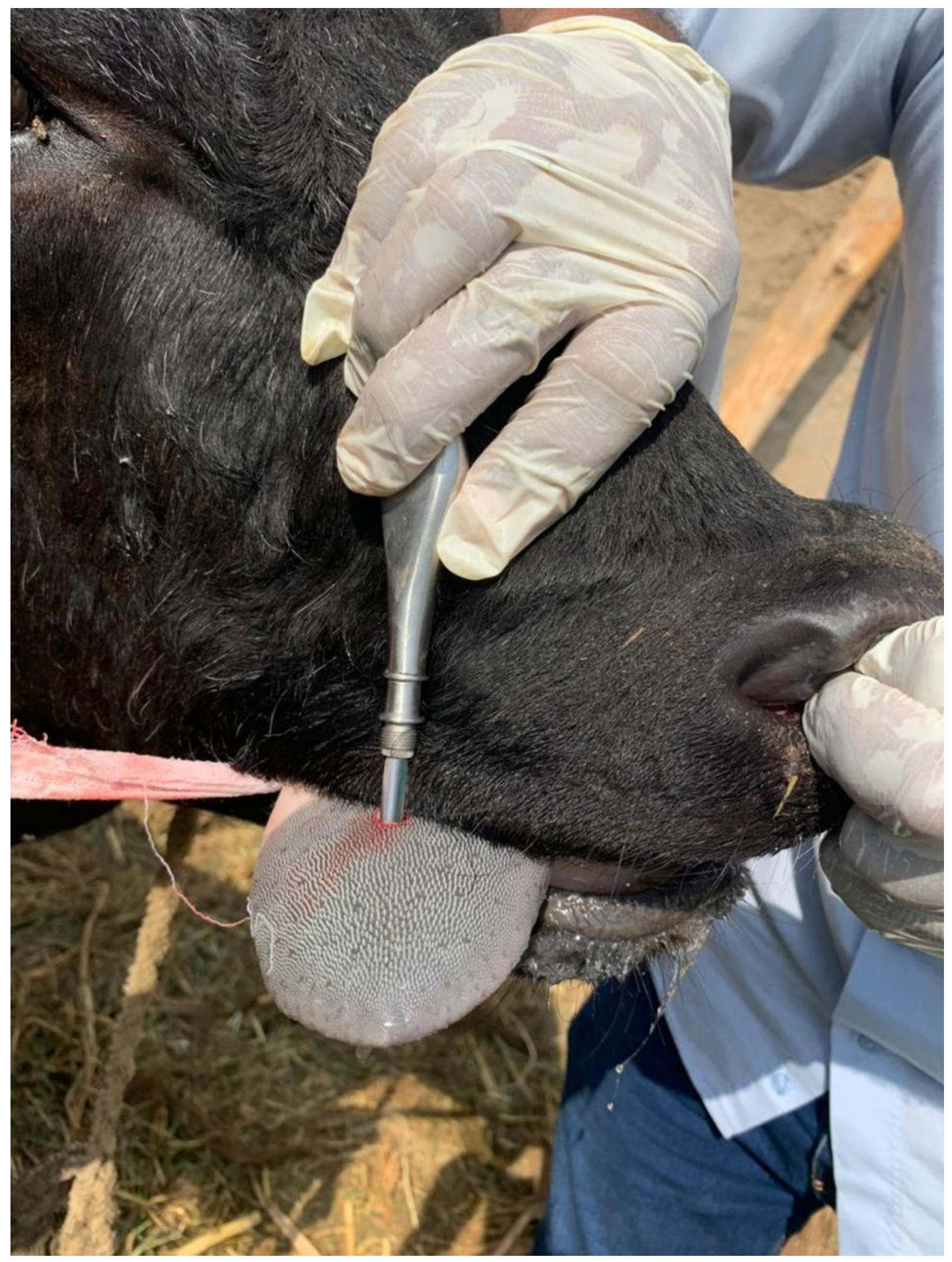

Figure 2

Trocarization of the tongue in the standing position. 


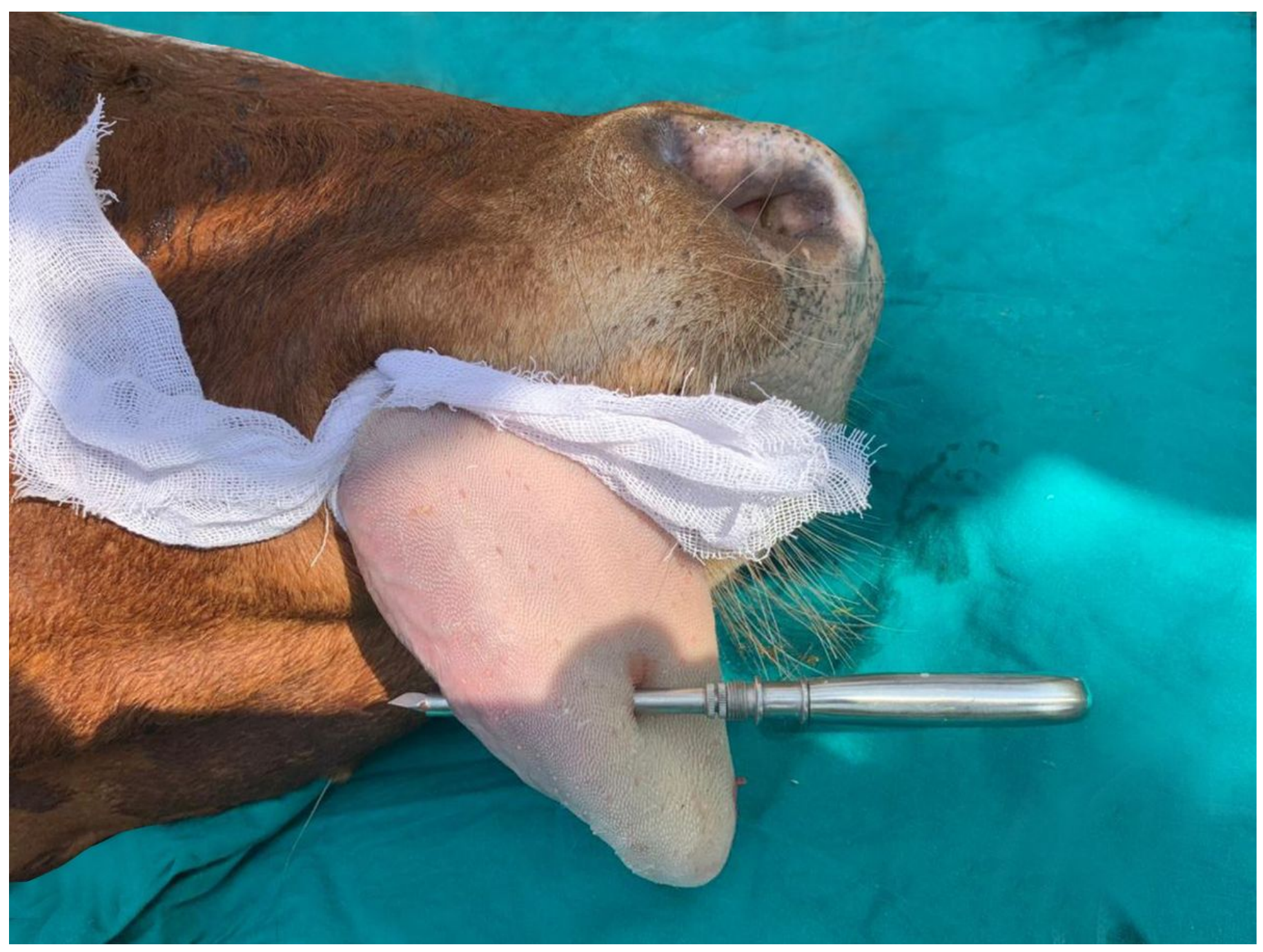

Figure 3

Trocarization of the tongue in the recumbent position. 


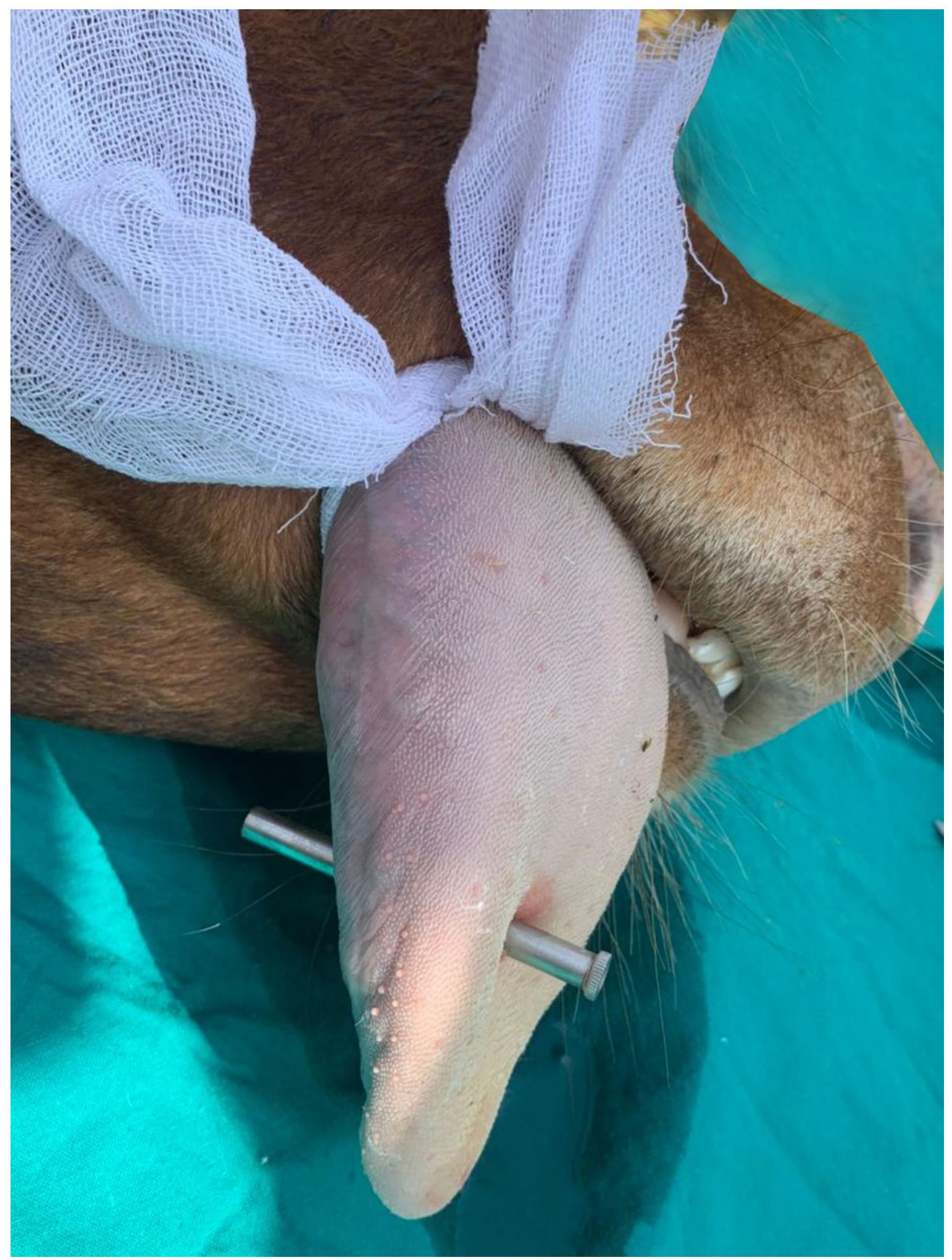

Figure 4

The cannula transverses the tongue. 


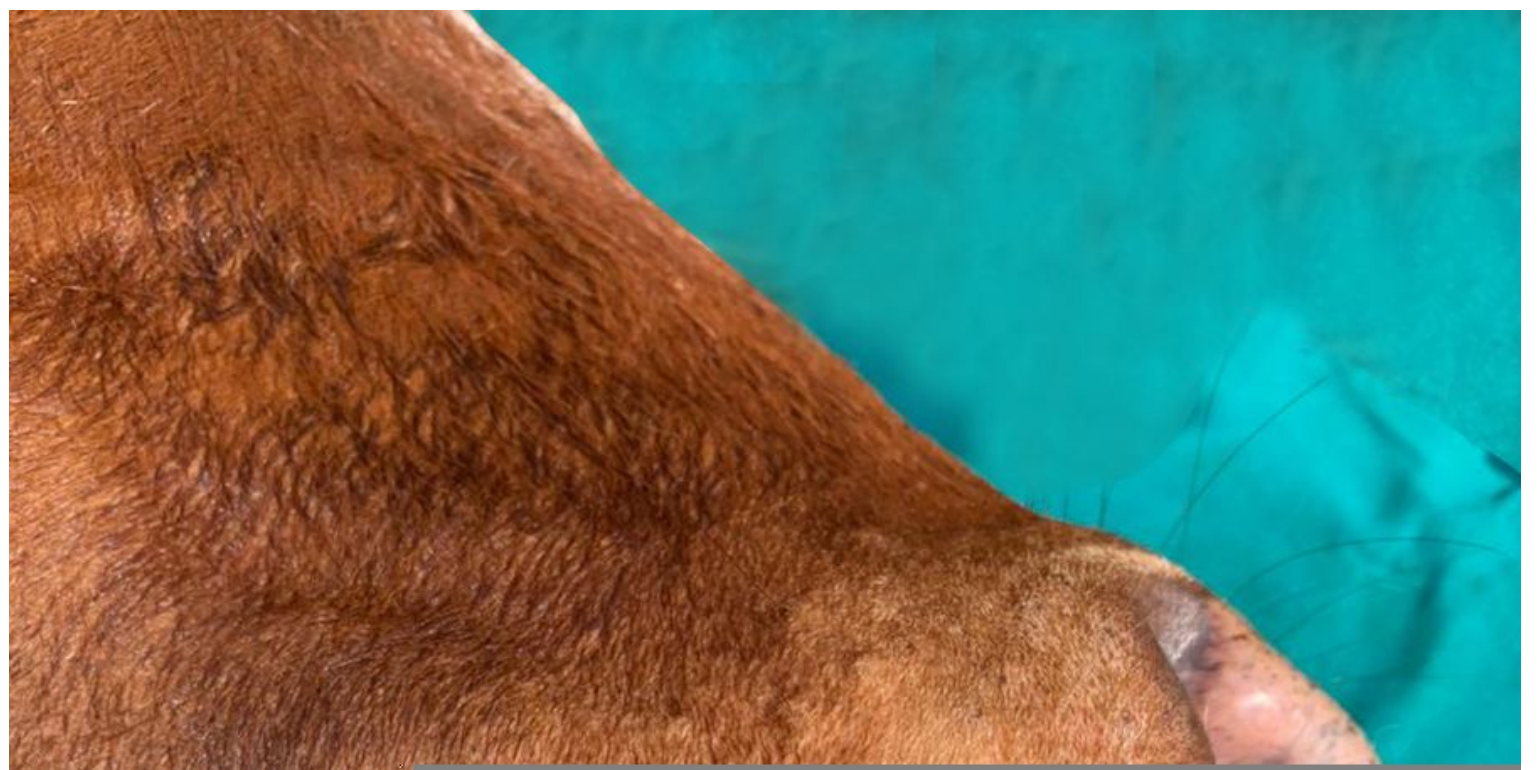

Figure 5

The implant from the dorsal surface of the tongue immediately after the operation. 


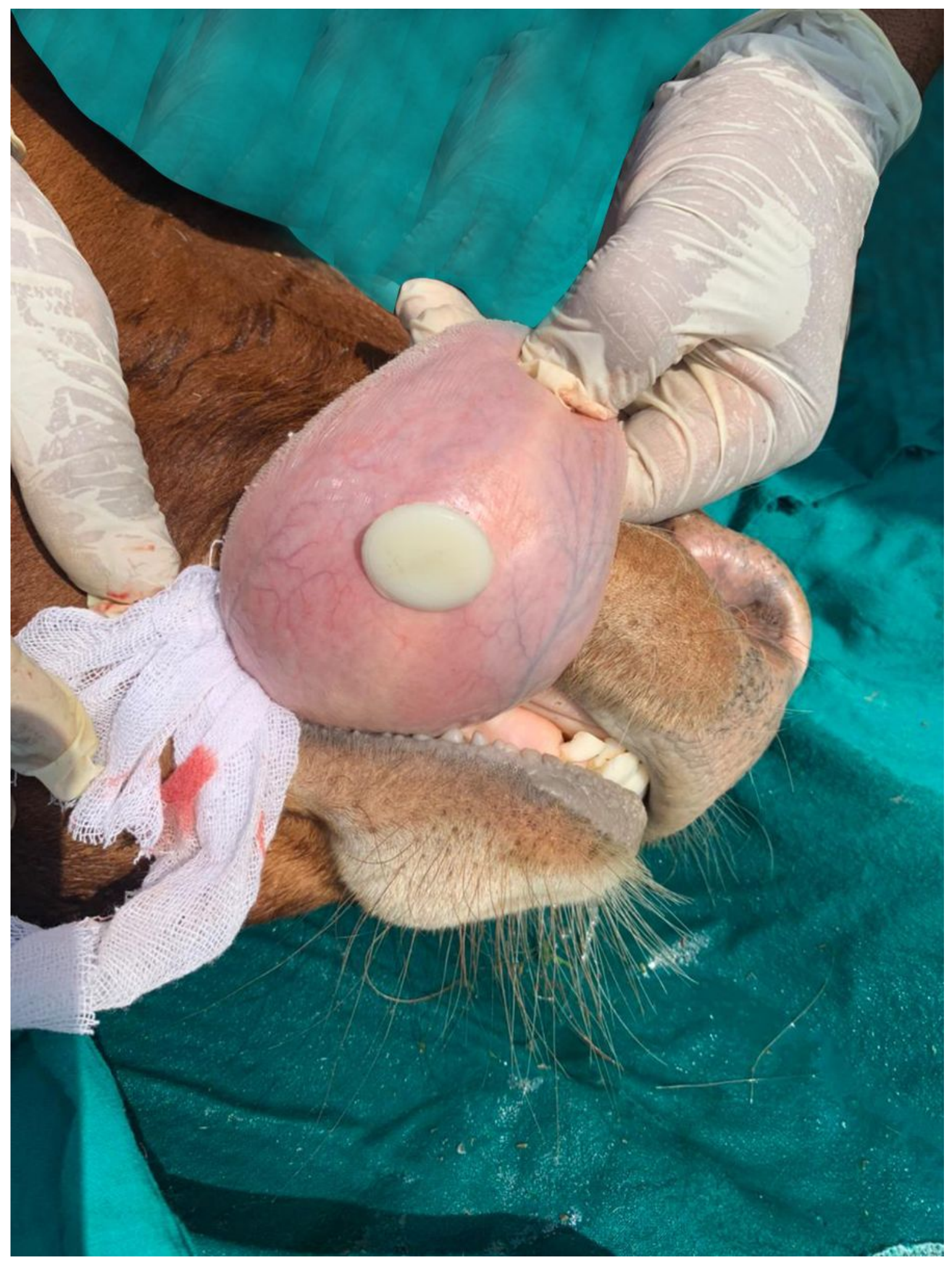

Figure 6

The implant from the ventral surface of the tongue immediately after the operation. 


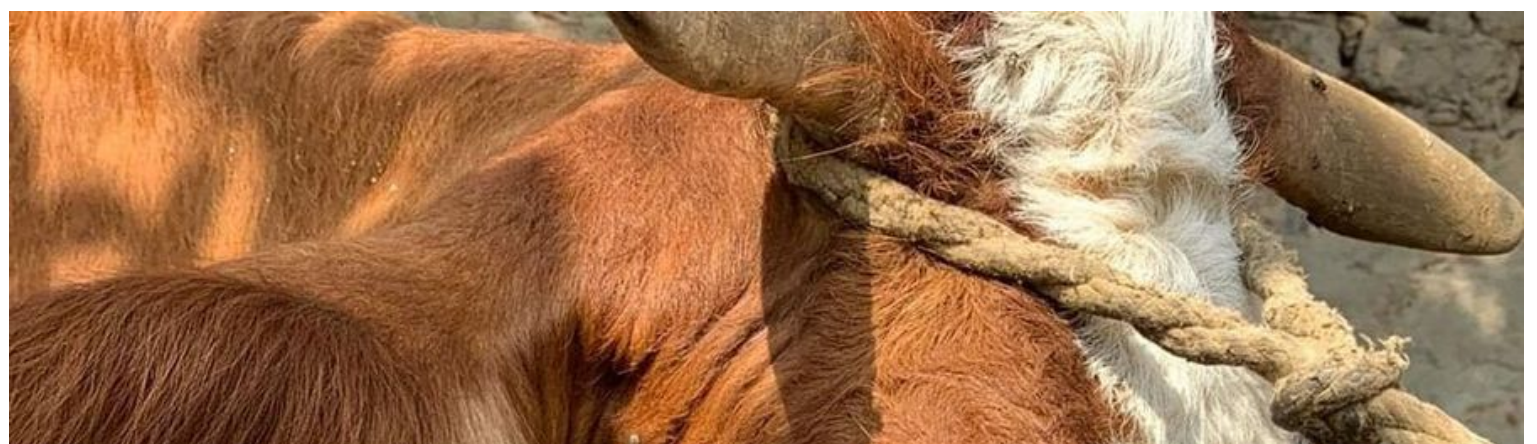

Figure 7

Tongue piercing after six months. 